\title{
DEVELOPMENT OF MODEL ON MOTHERS SELF-EFFICACY IN PREVENTING RECURRENCE OF NON-PNEUMONIA ACUTE RESPIRATORY INFECTION AMONG TODDLERS
}

\author{
Eliza Zihni Zatihulwani, Tintin Sukartini, Ilya Krisnana \\ Faculty of Nursing Universitas Airlangga, Kampus C Mulyorejo Surabaya, 60115 \\ Email: eliza.zihni@gmail.com
}

\begin{abstract}
Introduction: Acute Respiratory Infection (ARI) is the leading cause of morbidity and mortality in children. A cough and cold diseases such as rhinitis, pharyngitis, tonsillitis and other upper respiratory diseases are classified as non-pneumonia. ARIs that are not appropriately handled will affect the lung tissue and cause severity and even death. The purpose of this study is to develop a model of self-efficacy (SE) among mother to prevent recurrent (PR) non pneumonia (NP)-ARI on toddlers based on the integration of Precede-Proceed Model and Health Belief Model. Method: This study used crosssectional design. The population were a mother with a toddler in Tanggalrejo Village of Mojoagung Jombang. A hundred toddler's mothers were recruited as samples by cluster sampling. Variables in this study were predisposing-enablingreinforcing factors, main constructs of perceived (MCP), perceived threat, SE and PRNP-ARI. Data were collected using questionnaire, and Focus Group Discussion then analyzed using Partial Least Square (PLS). Results: The SE improvement model for the PRNP-ARI was formed from predisposing-enabling-reinforcing factors, MCP, perceived threat, and maternal SE. The greatest effect was on MCP against a perceived threat with $\mathrm{T}$ statistic value $=11.07$. Conclusion and recommendation: Increasing SE of toddler's mother can be done by educating mother about ARI concept, conventional ARI treatment, environmental modification, benefits of mask use, clean and healthy life behavior, proper hand washing, nutrition feeding, exclusive breastfeeding, stress management; create peer support group for toddlers mother; and optimizing the role of health officers and family support.
\end{abstract}

Keywords: Mother Self-Efficacy; Prevention Non-Pneumonia ARI

\section{INTRODUCTION}

Acute Respiratory Infection (ARI) is the leading cause of morbidity and mortality in children (IDAI, 2010). ARI that is not handled properly can cause pneumonia or even death. Cough and cold diseases such as rhinitis, pharyngitis, tonsillitis and other upper respiratory infections are classified as nonpneumonia (Kemenkes, 2012). Prevention recurrent non-pneumonia ARI will reduce the illness of children through ARI and reduce the risk of severe toddler conditions.

The incidence of non-pneumonia ARI in September 2016 from 34 Puskesmas in Jombang amount of 3,277 children under fiveyear-old. Puskesmas Mojoagung had the third largest incidence of non-pneumonia ARI. From January 2016 to August 2016 found the incidence of NP-ARI were 3,834 on toddlers and five cases of pneumonia. The largest number (540 toddlers) of NP-ARI was found in Tanggalrejo village. The preliminary study obtained that mother beliefs about the importance of prevention recurrent nonpneumonia ARI were still not convincing. Most of them remained to assume that the recurrent of Ari was normal and usual. However, Kemenkes explained some efforts to prevent the recurrence of NP-ARI include immunization of measles and pertussis, child nutrition improvement including the promotion of breastfeeding, improving health for pregnant women to prevent low birth weight (LBW), reducing inhouse or out-door populations, reducing population density, improving home ventilation, and improving health hygiene. Mother already know about the prevention, but not all of them can implement them. If a person believes a new behaviour is useful (perceived benefits), but does not think he or she is capable of doing it (perceived barriers), it is likely that the behaviour will not be adapted (Jones \& Bartlet, 2010). Self-efficacy will determine how a person feels, thinks, and motivates herself to act or behave (Bandura, 2013).

Self-efficacy is a person's belief about his ability in doing an activity that has a specific purpose that will affect his life (Bandura, 1997). In the other hand, selfefficacy is influenced by several factors consisting of performance accomplishment, vicarious experience, verbal persuasion, emotional arousal. The main construct of perceived and self-efficacy is part of Health Belief Model (HBM) (Rosenstock, 1974). 
HBM is a concept that reveals the reasons for the person to want or will not engage in healthy behaviour (Becker, 1984). The Health Belief Model (HBM) theory was used as the theoretical framework of this study by focusing on the mother self-efficacy for preventing recurrent non-pneumonia ARI. In addition to HBM studies, the Precede-Proceed model is used in complementing the development of HBM application models that would be built on mothers to prevent the recurrence of non-pneumonia ARI. The Precede-Proceed Model examines the issues of human behaviour and the factors that influence it, and how to follow up by trying to change, maintain or enhance the behaviour toward a more positive (Green, 1991). The study aimed to develop the model on mother self-efficacy preventing recurrence non-pneumonia ARI among toddlers based on the integration of Health Belief Model and Precede-Proceed Model. Further, this study can be used to improve the self-efficacy of the mother in the prevention of recurrent non-pneumonia ARI so that no toddler has pneumonia or even death.

\section{MATERIALS AND METHODS}

This study used cross-sectional approach and conducted in Tanggalrejo village in Mojoagung Jombang in March 2017. The population were 325 mothers with a toddler who registered in Posyandu, and 100 mothers with a toddler were recruited as samples by cluster sampling. The inclusion criteria in this study included: 1) mothers with toddlers (1-3 years); 2) Mothers who lived in the same house with children; 3) Mothers who have children with non-pneumonia ARI; 4) Mothers with toddlers registered at posyandu. While the exclusion criteria were mothers, who had toddlers with complicated diseases especially respiratory disease (example asthma).

The variables involve in this study were predisposing factors (mother's age, mother's education, family income, mother's knowledge, and mother's attitude), enabling factors (the use of health services and access to health resources), drivers or reinforcing factors sand family support), main perceived constructions (perceived susceptibility, perceived severity, perceived benefits, perceived barriers). Data were collected through questionnaires. The questions asked in the questionnaire of this study have been tested for validity and reliability. The validity of each item was tested using the Pearson Correlation using the level of significance of 0.05 . The reliability of the items was tested using Cronbach Alpha.

FGD was conducted on mothers who selected from the pool of survey. The FGD did twice, with eight toddler mother then six experts (one doctor, one programmer of ARI, one academician, three midwives). Data obtained were analyzed using SmartPLS 3. The Human Research Ethic Committee granted the ethic of this study from the Faculty of Nursing Universitas Airlangga under the letter number 346-KEPK dated February 17th, 2017.

\section{RESULTS}

In this study, the outer model was evaluated by testing the validity and reliability on the model and outer model evaluation by looking at the $\mathrm{T}$ statistic score. A validity test of the model can be seen from outer loading value in Table 1. It showed that three indicators were invalid (age $=0.30$, education $=0.47$, income $=0.13$ ) and sixteen indicators were valid with outer loading value $>0.5$. Three invalid indicators were excluded from the model. Outer loading value of predisposing factors consisting of two indicators: knowledge (0.61) and attitude (0.78); Enabling factors consisting of two indicators: the use of health services (0.89) and the accessibility of health resources $(0.81)$; Reinforcing factors consisting of two indicators, namely the role of health officer (0.95) and family support (0.71); Main perceived construction consist of four indicators: perceived susceptibility (0.71), perceived severity (0.69), perceived benefits (0.79), perceived barriers (-0.53); Perceived threat (1.00); Self efficacy which had four indicators of performance accomplishment (0.88), vicarious experience $(0.84)$, verbal persuasion (0.71), emotional arousal (0.51) and prevention of recurrent non-pneumonia ARI (1.00).

Table 2 showed the reliability test of the model. Reliability test can be seen from Cronbach alpha and composite reliability value. A construct or variable was said to satisfy the reliability test if it has a value of composite reliability $>0.7$ and the value of Cronbach alpha $>0.6$. Cronbach alpha value of 
Development of Model on Mothers Self-Efficacy in ... (Eliza Zihni, et.al.)

Table 1. Validity test results development of model on mothers self-efficacy in preventing recurrence of non-pneumonia acute respiratory infection among toddler in Tanggalrejo Village

\begin{tabular}{|c|c|c|c|c|}
\hline No. & Variable & Indicator & Outer loading & Description \\
\hline \multirow[t]{5}{*}{1.} & Predisposing factors & X1.1 Age & 0.302 & Invalid \\
\hline & & X1.2 Education & 0.476 & Invalid \\
\hline & & X1.3 Income & 0.139 & Invalid \\
\hline & & X1.4 Knowledge & 0.615 & Valid \\
\hline & & X1.5 Attitude & 0.787 & Valid \\
\hline \multirow[t]{2}{*}{2.} & Enabling factors & X2.1 Using of health services & 0.896 & Valid \\
\hline & & $\begin{array}{l}\mathrm{X} 2.2 \text { Accessibility to health } \\
\text { resource }\end{array}$ & 0.811 & Valid \\
\hline \multirow[t]{2}{*}{3.} & Reinforcing factors & X3.1 Role of health officer & 0.959 & Valid \\
\hline & & X3.2 Family support & 0.711 & Valid \\
\hline \multirow[t]{4}{*}{4.} & Main construct of & X4.1 Perceived susceptibility & 0.714 & Valid \\
\hline & perceived & X4.2 Perceived severity & 0.697 & Valid \\
\hline & & X4.3 Perceived benefits & 0.798 & Valid \\
\hline & & X4.4 Perceived barrier & -0.531 & Valid \\
\hline 5. & Perceived threat & & 1.000 & Valid \\
\hline \multirow[t]{5}{*}{6.} & Self-efficacy & X6.1 Performance & 0.886 & Valid \\
\hline & & accomplishment & 0.840 & \\
\hline & & X6.2 Vicarious Experience & 0.718 & Valid \\
\hline & & X6.3 Verbal Persuasion & 0.515 & Valid \\
\hline & & X6.4 Emotional arousal & & Valid \\
\hline 7. & $\begin{array}{l}\text { Prevention of recurrent } \\
\text { non- pneumonia ARI }\end{array}$ & & 1.000 & Valid \\
\hline
\end{tabular}

Tabel 2 Reliability test results development of model on mothers self-efficacy in preventing recurrence of non-pneumonia acute respiratory infection among toddler in Tanggalrejo Village

\begin{tabular}{llccl}
\hline No. & Variable & Cronbach Alpha & Composite Reliability & Description \\
\hline 1. & Predisposing factors & 0.326 & 0.595 & Invalid \\
2. & Enabling factors & 0.600 & 0.832 & Valid \\
3. & Reinforcing factors & 0.652 & 0.829 & Valid \\
4. & Main construct of perceived & 0.210 & 0.575 & Invalid \\
5. & Perceived threat & 1.000 & 1.000 & Valid \\
6. & Self-efficacy & 0.743 & 0.835 & Valid \\
7. & Prevention of recurrent non- & 1.000 & 1.000 & Valid \\
& pneumonia ARI & & & \\
\hline
\end{tabular}

enabling factors (0.60), reinforcing factors (0.65), perceived threat (1.00), self-efficacy (0.74), and prevention of recurrent nonpneumonia ARI (1.00) were satisfied reliability test. Cronbach alpha value of predisposing factors $(0.32)$ and main constructs of perceived $(0.21)$ was not satisfied reliability test. The values of the composite reliability of enabling factors (0.83), reinforcing factors $(0.65)$, perceived threat (1.00), self-efficacy (0.83), and prevention of recurrent non-pneumonia ARI (1.00) were satisfied reliability test. The values of the composite reliability of predisposing factors (0.59) and main constructs of perceived (0.57) were not satisfied reliability test. Based on the expert's recommendation, all the constructs or variables were tested in the model because all of the variables support the prevention of recurrent non-pneumonia ARI.

Table 3 showed the hypothesis test. There was a significant influence if the variables had value $\mathrm{T}>1$. From Table 3 , it can be seen that (1) There was a significant 
Tabel 3. Hypothesis test results development of model on mothers self-efficacy in preventing recurrence of non-pneumonia acute respiratory infection among toddler in Tanggalrejo Village

\begin{tabular}{|c|c|c|c|c|c|}
\hline No. & Variabel & Path Coefisien & $\begin{array}{r}\text { Standard } \\
\text { Deviation }\end{array}$ & T Statistics & Explanation \\
\hline 1. & $\begin{array}{l}\text { Predisposing factor } \\
\text { toward main perceived } \\
\text { construction }\end{array}$ & 0.276 & 0.098 & 2.808 & Significant \\
\hline 2. & $\begin{array}{l}\text { Enabling factors } \\
\text { toward main perceived } \\
\text { construction }\end{array}$ & 0.260 & 0.094 & 2.776 & Significant \\
\hline 3. & $\begin{array}{l}\text { Reinforcing factors } \\
\text { toward main perceived } \\
\text { construction }\end{array}$ & 0.231 & 0.102 & 2.255 & Significant \\
\hline 4. & $\begin{array}{l}\text { Main perceived } \\
\text { construction toward } \\
\text { self-efficacy }\end{array}$ & 0.597 & 0.073 & 8.205 & Significant \\
\hline 5. & $\begin{array}{l}\text { Main perceived } \\
\text { construction toward } \\
\text { perceived threat }\end{array}$ & 0.670 & 0.061 & 11.073 & Significant \\
\hline 6. & $\begin{array}{l}\text { Perceived threat toward } \\
\text { prevention }\end{array}$ & 0.218 & 0.081 & 2.698 & Significant \\
\hline 7. & $\begin{array}{l}\text { Self efficacy toward } \\
\text { prevention }\end{array}$ & 0.350 & 0.087 & 4.009 & Significant \\
\hline
\end{tabular}

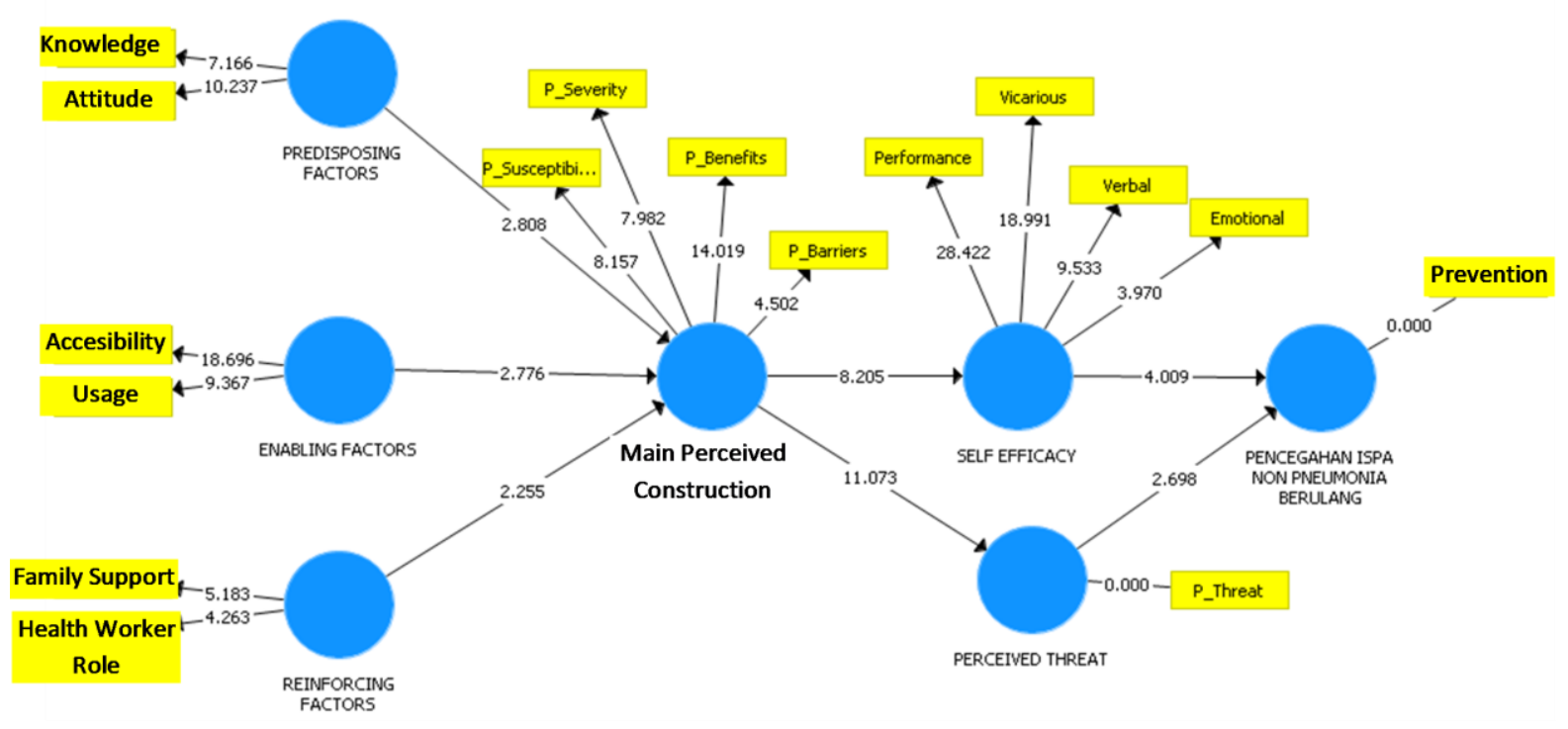

Figure 1. Analysis test results development of model on mothers self-efficacy in preventing recurrence of non-pneumonia acute respiratory infection among toddler in Tanggalrejo Village

influence between predisposing factors toward main perceived construction $(\mathrm{T}=2.80)$. (2) There was a significant influence between enabling factors toward main perceived construction $(\mathrm{T}=2.77)$. (3) There was a significant influence between reinforcing factors toward main perceived construction $(T=2.25)$. (4) There was a significant influence between main perceived construction toward self-efficacy $(\mathrm{T}=8.20)$. (5) There was a significant influence between main perceived construction toward perceived threat 
( $\mathrm{T}=11.07)$. (6) There was a significant influence between perceived threat toward prevention of recurrent in pneumonia ARI $(T=2.69)$. (7) There was a significant influence on self-efficacy toward prevention of recurrent in pneumonia ARI $(\mathrm{T}=4.00)$. Analysis test results development of model can be seen in figure 1.

Recommendation results of FGD with mothers with toddler and experts: 1) Increase awareness of health workers to provide education and evaluate programs about ARI and prevention of recurrent NPARI. 2) Mothers with toddler should be educated routinely about ARI and prevention of recurrent NP-ARI by an easy-to-understand method, include the risk of recurrent nonpneumonia ARI in toddlers, clean and healthy behavior and proper hand washing, immunization, providing vitamin A and good nutrition, exclusive breastfeeding, stress management, signs-symptoms and the emergency of ARI and the use of mask. 3) Mothers with toddler and families need to know how to modify the environment to prevent recurrent NP-ARI in toddlers. 4) Improve the function of village's clinic that supported by health workers and good facilities. 5) Make the peer group among mothers with a toddler for support each other.

All the result of this study were integrated into the module as a guide to increase mother self-efficacy in preventing recurrence of non-pneumonia ARI.

\section{DISCUSSION}

\section{Predisposing Factors in Forming the Main Perceived Construction}

The PLS analysis showed that there was a significant influence between predisposing factors toward main perceived construction. The PLS analysis results on the indicator of predisposing factors obtained that the value of outer loading met the level of knowledge and attitude. In line with that, the results of Guvenc, Seven and Akyuz (2016) shows that high knowledge will increase perceived susceptibility, perceived severity and perceived benefits, and decrease perceived barriers.

Based on the questionnaires, almost all respondents had good knowledge. The finding from FGD showed that mothers with a toddler knew non-pneumonia ARI based on their experience, either their own experience or others experience. This result was in line with notoatmojo's opinion that experience was onefactor influence knowledge (Notoatmojo, 2012). However, for non-pneumonia ARI terminology has not understood but they understood about a cough, runny nose and breathlessness or respiratory disorders. Mothers with a toddler who knows good prevention of recurrent non-pneumonic ARI can improve the perception in preventing recurrent of non- pneumonia ARI.

This study showed that most respondents had a positive attitude. Based on FGD, the habit was the most difficult cause to change attitude. Habits related to the prevention of recurrent non-pneumonia ARI, such as smoking by family members, the used of masks on family members who were experiencing ARI, and awareness to maintain personal hygiene were difficult to change. Positive attitude toward the prevention of recurrent non-pneumonia ARI will increase the main perceived construction in preventing of recurrent non-pneumonia ARI. This result was in line with Robbin opinion; perceptions are influenced by attitudes, motives, interests, experiences, and expectations (Robbins, 2006).

\section{Enabling Factors in Forming the Main Perceived Construction}

Enabling factors manifest in the physical environment and the availability of health facilities. Enabling factors include the using of health services, accessibility to health resources, government regulations, and health skills (Green, 1991). This study only uses health services and accessibility of health resources as indicators of supporting factors. The PLS analysis result showed that there was a significant influence between the variable of enabling factors toward main perceived construction.

The using of health services greatly affects the severity of ARI. In some developing countries, the utilization of health facilities is still low. The using of health facilities could reflect the high incidence of ARI, that was $60 \%$ of outpatient visits in Puskesmas and $20-40 \%$ of outpatient visited in hospitals (IDAI, 2010). The results show that there is a relationship between the use of health services with the public's health 
perception (Napirah et al., 2016). Similar to this study, Wahyuni (2012) shows that there was a significant relationship between the utilisation of health services with the illness perception. It can be seen from the survey that the availability of health services, affordable costs and excellent health services were important factors to prevent the recurrence of a pneumonia ARI. FGD showed that mothers with a toddler took their toddlers to health services such as Puskesmas or to private health services when they had ARI.

The choice of using health service facility was due to the suitability or cost reason. Mothers who choose to took their toddlers to private health services because they felt that there was no change in their condition after took at the Puskesmas. However, there were mothers who still took their toddlers to the puskesmas for free services. Good health services will increase the main perceived construction in preventing of recurrent nonpneumonia ARI.

Accessibility is an indicator of the place to be easily reached from other locations through the transport system. Indicators of affordability include the time, cost, and way in moving from place to another place. Some factors that affect accessibility include distance, transportation network, road availability, transportation facilities, and road quality (Muta'ali, 2015). There was a relationship between travel time and the use of health facilities (Nainggalon, 2012). Retnaningsih et al. (2007) show that variables related to respondent's access to health service are knowledge, health insurance, advice, cost, and distance to health service (Retnaningsih, 2007).

Health-source accessibility was found to be well accessibility. It can be seen from the distance, cost and transportation facilities to reach health services. FGD showed that village clinic could be used for treatment including toddlers who had non-pneumonia ARI. Good health source's accessibility will increase the main perceived construction in preventing recurrent non-pneumonia ARDs.

\section{Reinforcing Factors in Forming the Main Perceived Construction}

Reinforcing factors manifest in attitudes and behaviours of health workers, peers, parents, and community reference groups. Reinforcing factor consist of family, peers, teachers, co-workers, health workers, traditional leaders, and decision makers. PLS analysis showed that there was a significant influence between reinforcing factors toward main perceived construction. This study only uses the role of health worker and family support as variables.

Result study showed that the role of health care workers is related to the mother's perception and may affect mother's behaviour. In line with this study, Asri (2013) reported a relationship between the role of healthcare workers and behavioural changes. There was a relationship between perception of the mother about the role of health workers in preventing pneumonia (Wahyuningsih, 2013).

Health worker played a significant role in educating mothers. It can be seen from the frequency and implementation of education. Experts in FGD revealed that the ARI counselling was given once in three months. FGD also indicated existing programs and implementation of education program in the community should be alignment. Thus, it was expected that mothers with a toddler could get the proper information about the prevention of recurrent in pneumonia ARI. Good role of health worker will improve the main perceived construction in preventing recurrent nonpneumonia ARI.

Family support in this study focused on emotional, appreciation, information and instrumental support. Study of Bahar (2013) shows that family support related to exclusive breastfeeding behaviour. In line with this study, family support affects a person's behaviour. In this study, the family was an important factor in preventing recurrent nonpneumonia ARI in toddlers. Families should realize the importance of prevention of recurrent non-pneumonia, so they expected to improve their effort in preventing recurrent non pneumonia ARI. Good family support will improve the main perceived construction (primary perceptual construction) in preventing recurrent non-pneumonia ARI.

\section{Main Perceived Construction in Forming the Perceived Threat}

The PLS analysis result showed that there was a significant influence on main perceived construction toward the perceived threat. The results of perceived threat indicated that the respondents had a high score. It was seen from the perception of threat through 
several aspects, which are: vitamin deficiency, incomplete immunisation, history of exclusive breastfeeding, non-supportive environment, the impact of recurrent non-pneumonia ARI.

Mother with toddler FGD results were found that some mothers who did not give exclusive breastfeeding. Following up on this, FGD experts discussed the importance of exclusive breastfeeding socialisation on how to exclusive breastfeeding and tools hygiene when using ASIP (breast milk).

\section{Perceived Threat in Forming the Prevention of Recurrent Non-Pneumonia ARI}

In this study, health promotion that could be given starting from the concept of ARI, ARI care, environmental modification, PHBS or Clean and Healthy Behavior Program, hand washing, balanced nutrition, breastfeeding. Special protection was done by immunization. Disability restrictions by alerting alertness to ARDs. Rehabilitation was done to maintain the quality toddlers life. Prevention is the effort to direct some activities to protect clients from potential health threats. According to Leavell and Clark there are five levels of prevention, including health promotion, specific protection, early diagnosis and prompt treatment, and also disability limitation.

PLS analysis results showed that there was a significant influence between perceived threat variables on the prevention of recurrent no-pneumonia ARI. The study shows that perceived threat have a positive relationship to behavioural change (Sundstrom et al., 2015). Efforts to ARI prevention include immunisation against measles and pertussis, improving child nutrition including promotion of breastfeeding, improving health for pregnant women to prevent low birth weight (LBW), reducing in-house or out-of-home populations, reducing the population.

The prevention of non-pneumonia ARI recurrent showed that the behaviour of providing nutritious food, environmental modification, immunisation completion, exclusive breastfeeding, vitamin A administration. Based on FGDs results with experts, it was necessary to socialise the prevention and treatment of non-pneumonia ARI easily or traditionally and to review the need for medical treatment such as a nebulizer.

\section{Self-Efficacy in Forming the Prevention of Recurrent Non-Pneumonia ARI}

PLS analysis results showed that there was a significant influence between selfefficacy toward the prevention of recurrent non-pneumonia ARI. In line with the results, the study about self-efficacy showed that selfefficacy as a predictor of behaviour (Buglar, White and Robinson, 2010). In the Sundstorm (2015) study, the behaviour change influenced by perceptions of susceptibility, severity, benefits, barriers, self-efficacy and cues to action. Based on FGD, most of their family members smoking at home. Mothers also acknowledged that it was challenging to change smoking of family member inside the house.

The vicarious experience showed that largely an experience gained from others. Based on the FGD, the experience of others could trigger the mother to keep the toddler's health including doing the prevention of recurrent non-pneumonia ARI. Based on the results of FGD found that it was hard to prevent children from play outside the house. The emotional arousal had good value for each item of the statement. Based on the results of FGD found that most toddlers felt anxious when toddlers had ARI.

Prevention of disease is the effort to direct some activities to protect clients from potential health threats. Efforts to prevent ARI include immunization against measles and pertussis, improving child nutrition such as breastfeeding promotion, improving health for pregnant women to prevent low birth weight (LBW), reducing in-house or out-of-home populations, reducing population density, home ventilation addition, health hygiene improvement (Kemenkes, 2012).

Results showed that the prevention of recurrent non-pneumonia ARI of some mothers with toddlers was good. Based on FGD results showed that they were almost never used a mask when they had ARI. They were still lack of confidence in preventing the non-pneumonia ARD recurrence. They considered that non-pneumonia respiratory problem was a common and reasonable event. Mothers with toddlers were less aware that non-pneumonia ARI can cause complications if not treated properly. Also, respondents also do not understand that non-pneumonia ARI can be prevented. Good self-efficacy is 
expected to improve the prevention of nonpneumonia ARI recurrence.

\section{CONCLUSIONS}

Mother self-efficacy improvement model toward prevention of recurrent nonpneumonia ARI on toddlers can be formed by predisposing factors, enabling factors, main perceived construction, perceived threat, selfefficacy and prevention of recurrent nonpneumonia ARI. The greatest result was in the influence of main perceived construction to perceived threat $(\mathrm{T}=11.07)$. Increasing selfefficacy of mothers with toddler can be done by educating about ARI concept, conventional ARI treatment, environmental modification, benefits of using mask, clean and healthy life behavior, proper hand washing, nutrition feeding, exclusive breastfeeding, stress management; create peer group support for toddlers mother; and optimizing the role of health officers and family support.

Mothers with a toddler and their family need a simple health education about ARI and prevention of recurrent NP-ARI. Mothers with toddler need to make peer group to share information and experience in preventing recurrent NP-ARI. The results of the study can be used to review the policy of existing ARI control programs. Further research is expected to examine the relationship of other variables in precede proceeded model or on the health belief model in preventing of recurrent non-pneumonia ARI on toddlers.

\section{REFERENCES}

Asri, N. (2013) Hubungan Peran Petugas Kesehatan dan Media Informasi dengan Perilaku Seksual Pada Ibu Pasca Nifas di Wilayah Kerja Puskesmas Peukan Bada Kabupaten Aceh Besar. Sekolah Tinggi Ilmu Kesehatan U'budiyah BAnda Aceh.

Bahar, B. (2013) Hubungan Antara Karakteristik Ibu, Peran Pettugas Kesehatan, dan Dukungan Keluarga dengan pemberian ASI Eksklusif di Wilayah Kerja Puskesmaas BOnto Cani Kabupaten Bone. Fakultas Kesehatan Masyarakat Universitas Hasanuddin Makasar.

Bandura (1997) Self Efficacy: The Exercise of Control. New York: W.H. Freeman and Company.

Bandura, A. (2013) 'Self Efficacy', Kognitiog paedagogik, (83), pp. 16-35.

Becker, J. \& (1984) 'The Health Belief Model: A decade Later', Health Education Quarterly, 1(11), pp. 1-47.

Buglar, M. E., White, K. M. and Robinson, N. G. (2010) 'Patient Education and Counseling The role of self-efficacy in dental patients, brushing and flossing: Testing an extended Health Belief Model', 78, pp. 269-272. doi: 10.1016/j.pec.2009.06.014.

Green (1991) Health Promotion Planning. An Educational and Environment Approach. 2nd edn. ED. Mountain View: Mayfield Publishing Co.

Guvenc, G., Seven, M. and Akyuz, A. (2016) 'Health Belief Model Scale for Human Papilloma Virus and its Vaccination: Adaptation and Psychometric Testing', Journal of Pediatric and Adolescent Gynecology. Elsevier Inc, 29(3), pp. 252-258. doi: 10.1016/j.jpag.2015.09.007.

IDAI (2010) Buku Ajar Respirologi Anak. Pertama. Jakarta: Badan Penerbit IDAI.

Jones \& Bartlet (2010) 'Helath Belief Model', in Design and implementation of AN OSTEOPOROSIS prevention program using the health belief program, pp. $31-44$.

Kemenkes (2012) Pedoman Pengendalian Infeksi Saluran Pernafasan Akut. Jakarta: Kementrian Kesehatan Republik Indonesia.

Muta'ali, L. (2015) Teknik Analisis Regional Untuk Perencanaan Wilayah, Tata Ruang dan Lingkungan, Yogyakarta: Badan Penerbit Fakultas Geografi. Yogyakarta: Badan Penerbit Fakultas Geografi.

Nainggalon (2012) 'Hubungan Perilaku Ibu dengan Peran Petugas Kesehatan di Wilayah Kerja Puskesmass NAmorambe Kecamatan Deli Tua', Universitas Sumatera Utara, 17.

Napirah, M. R. et al. (2016) 'FAKTORFAKTOR YANG BERHUBUNGAN UTARA KABUPATEN POSO', 7062. doi: 10.14710/jpk.4.1.29-39.

Notoatmojo, S. (2012) Promosi Kesehatan dan Perilaku Kesehatan. Jakarta: Rineka Cipta. 
Development of Model on Mothers Self-Efficacy in ... (Eliza Zihni, et.al.)

Retnaningsih (2007) 'Analisis Multilevel Model Akses Layanan Kesehatan Suspek Pederita Tuberkulosis di Indonesia', Buletin Panel Kesehatan, 4(35), pp. 156-166.

Robbins (2006) Perilaku Organisasi. Edisi Baha. Pearson education.

Rosenstock (1974) 'Historical Origin of The Health Belief Model', Health Behaviour \& Education, pp. 328-335. doi: $10.1177 / 109019817400200405$.

Sundstrom, B. et al. (2015) 'Protecting the
Next Generation: Elaborating the Health Belief Model to Increase HPV Vaccination Among College-Age Women', 21(3), pp. 173-188. doi: $10.1177 / 1524500415598984$.

Wahyuningsih (2013) HUbungan persepsi Ibu Tentang peran Serta tenaga Kesehatan dengan Perilaku Pencegahan pneumonia pada Ibu Balita Usia 1-5 Tahun di Puskesmas Ngesrep KOta Semarang. Universitas Muhammadiyah Semarang. 